\title{
MAKALE KABUL KOŞULLARI VE YAZIM KURALLARI
}

- Dergide çevre bilimleri alanında yapılmış özgün araştırmalar ve derlemeler (tarama yazıları) yayınlanır. Dergide yayınlanacak eserler Türkçe ya da İngilizce olarak yazılabilir.

- Dergiye gelen eserin basımı öncesinde hakem görüşleri alınır. Gönderilen makalenin dergide yayınlanabilmesi için Editörler Kurulu tarafından hem bilimsel içerik, hem de şekil bakımından uygun görülmesi ve hakemler tarafindan kabul edilmesi gerekir. Yayınlanması uygun bulunmayan eser yazarına/yazarlarına geri gönderilir.

- Dergide yayınlanacak eserin daha önce hiçbir yayın organında yayınlanmamış ya da yayın hakkının verilmemiş olması gerekir. Buna ilişkin yazılı bildirim, makale ile gönderilmelidir.

- Eser, Microsoft Word Windows programında, Times New Roman yazı karakterinde yazılarak, CD ile birlikte, 1 bilgisayar çıktısı, 2 fotokopi olmak üzere toplam 3 nüsha gönderilmelidir. Eserin 2 nüshasında yazar adı ve kurumu yer almamalıdır.

- Makale A4 normunda birinci hamur kağıda, sayfa kenar boşlukları üst $3 \mathrm{~cm}$, sol $2,5 \mathrm{~cm}$, sağ $2,5 \mathrm{~cm}$, alt $4 \mathrm{~cm}$ olarak ayarlanarak, PC ortaminda, Microsoft Word programinın yeni versiyonunda, 11 punto Times New Roman karakteri ile, tek satır aralığ 1 kullanarak ve iki yana yaslı olarak hazırlanmalı, paragraf arası verilmemeli, paragraflarda ilk satır girintisi ise $1.25 \mathrm{~cm}$ olarak yazılmalı, metin içerisinde tablo ve şekiller dahil koyu karakterlere yer verilmemeli, şekil, çizelgeler ve Kaynaklar bölümü dahil 15 sayfayı geçmemelidir.

- Eser başlığı baş harfleri büyük, ortalanarak koyu (bold) ve 14 punto, yazar adları 12 punto, Özet ve Abstract iki yana yasli 9 punto ile yazılmalıdır.

- Yazar adı/adları açık olarak yazılmalı, ünvan kullanılmamalı, adres bilgileri 11 punto ve italik olacak şekilde bir alt satırda yer almalıdır. Başlık ile yazar isimleri arasında 1,5 satır aralığı bulunmalıdır. İki ya da daha fazla yazarlı makalelerde, yazarların soyadları üzerine rakam konularak, adres bilgileri alt satırda ve tek satır boşluğu bırakılarak yer almalıdır.

- Yapılan çalışma bir kurum/kuruluş tarafından desteklenmiş ya da doktora/yüksek lisans tezinden hazırlanmış ise, başlığa yıldız koyularak ilk sayfanın altına dip not olarak verilmelidir.

- Özgün araştırmalar; Özet, Abstract, Giriş, Materyal ve Yöntem, Bulgular, Tartışma, Sonuç, Teşekkür (gerekirse), Kaynaklar şeklinde düzenlenmelidir. Derlemeler Giriş, uygun başlıklar altında Ana Metin ve Sonuçlar olmak üzere üç bölümden oluşabilir, yayınlanmasında Ankara Üniversitesi Çevrebilimleri Dergisinin Yayın İlkeleri uygulanır. Özet, 200 kelimeyi aşmayacak şekilde, çalışmanın amacını, nasıl yapıldığını, sonuçları ve sonuçlar üzerine yazar(lar)ın yaptığ kullanılmalıdır. Giriş, çalışmanın önemini, amacını ve konu ile ilgili daha önce yapılmış temel araştırmaları kapsamalıdır. Materyal ve Yöntem, çalışmanın tekrarına olanak verecek şekilde yeterli bilgi ve kaynakları içermelidir. Bulgular, şekil ve çizelgelerde verilen bilgilerin tam olarak anlaşılmasını sağlamalıdır. Tartışma bölümünde sonuçlar, önemi vurgulanarak daha önce yapılan çalışmalarla karşılaştırılmalıdır. Sonuç bölümünde ise, bulgulardan ulaşılan son değerlendirmeler verilmelidir.

- Makaledeki şekil, harita ve fotoğrafların bilgisayar kayıtları, kaliteli basıma uygun yüksek çözünürlükte olmalı, makalede metin içerisine yerleştirilmeli ve baskı aşamasında orijinalleri de makaleyle birlikte gönderilmelidir. Çizelge başlıkları çizelgenin üstüne, çizelge kaynağı ise altına verilmelidir. Çizelge ve şekil açıklamalarında sadece ilk kelimenin baş harfi büyük, diğerleri küçük harflerle yazılmalıdır. Çizelge içerisindeki metinlerde de aynı kural geçerlidir. Tüm tablolar "Çizelge"; tüm grafik, harita ve çizimler "Şekil" olarak adlandırılmalıdır. Şekil 
adları şeklin altında verilmelidir. Tüm şekil ve çizelge adları 9 punto, Times New roman karakterinde olmalı, numaralandırmalardan sonra nokta verilmelidir.

- Metin içerisinde atıfta bulunulan kaynaklar, yazarın soyadı ve yayın yılı sıralamasıyla parantez içerisinde verilecektir (Akpınar, 2000). Aynı yazarın aynı tarihli birkaç eseri varsa alıntılarda yıldan sonra a,b,c... şeklinde numaralandırma yapılacaktır (Akpınar, 2002a). Birden fazla esere atıfda bulunuluyorsa referanslar alfabetik sıra ile verilmelidir (Avcıoğlu, 2002; Oğuz, 2004; Uslu ve Kiper, 2005).

- Sözlü görüşmeler ve yayınlanmamış eserlere (Yüksek Lisans ve Doktora Tezleri hariç) ait bildirimler, kaynak olarak kullanılmamalıdır.

- Kaynaklar listesi ilk yazarın soyadına göre alfabetik olarak düzenlenmelidir. İki veya daha fazla yazarlı eserlerin bildiriminde son yazardan önce "ve" bağlacı kullanılmadır.

Dergi:

Somuncu, M. 2004. Dağcıllk ve Dağ Turizmindeki İkilem: Ekonomik Yarar ve Ekolojik Kitap: Bedel. Coğrafi Bilimler Dergisi, 2 (1):1-22.

Keleş, R. 1996. Kentleşme Politikası. İmge Kitabevi Yayınları: 803, Ankara.

Kitabın bir bölümü:

Hamamc1, C. 1997. Çevrenin Uluslararası Boyutları. s: 395-412. Editör: R. Keleş. İnsan Çevre Toplum. İmge Kitabevi, Ankara.

\section{Bildiri kitabı:}

Karadeniz, N., Özbek, H. ve Gül, S. 2000. Ülkemiz Koruma Alanlarında Yönetim Planı Süreci. 2000’li Yıllarda Yaşadığımız Çevre ve Peyzaj Mimarlığı Sempozyumu. Bildiriler Kitabı: 177-184, 24-26 Mayıs 2000, Ankara.

Yazarı belirtilmeyen kurum yayınları:

Anonim 1997. Ulusal Çevre Eylem Planı: Arazi Kullanımı ve Kıyı Alanlarının Yönetimi. İnternet sayfaları:

Devlet Planlama Teşkilatı Yayını, Ankara.

İnternet sayfasına atıfta metin içerisinde Anonim ya da Anonymous ve erişim tarihi olarak verilmeli (Anonim, 2005), Kaynaklar bölümünde ise sayfa adresi de verilmelidir.

Anonymous 2007. Explore Europe's changing landscape.

http://www.eea.europa.eu/highlights/ explore-europe2019s-changing-landscape.

- Etik Kurul onayı gerektiren çalışmalarda, Etik Kurul onayına dair belge gönderilmesi ve makalede de Etik Kurul onayı alındığının belirtilmesi gerekmektedir.

- Basımına karar verilen eserde, ekleme ya da çıkarma yapılamaz.

- Makalelerle birlikte posta işlemlerinde kullanılmak üzere 10 TL'lik posta pulu gönderilmelidir.

- Yayın süreci tamamlanan eserler geliş tarihi esas alınarak yayınlanır.

- Bir yazarın, aynı sayıda ilk isim olarak 1 (bir), ikinci ve diğer isim sırasında 1 (bir) olmak üzere toplam 2 (iki) eseri basılabilir.

- Sayfa sınırını aştığı için seri makale olarak bölünmesi söz konusu olan araştırmaların başlıkları ona göre düzenlenerek, zaman içinde sırayla basılmak üzere, değerlendirmeye bir arada sunulmalıdir.

- Yayınlanan eserin tüm sorumluluğu yazarına/yazarlarına aittir. 